\title{
Ebeveynlerin Sağlık Okuryazarlığı Düzeyinin Çocukluk Dönemi Aşılarına Yönelik Tutum ve Davranışlarıyla iliş̧kisi \\ $\infty$
}

\author{
Bekir ERTUĞRUL' ${ }^{1}$, Sevil ALBAYRAK ${ }^{2}$
}

\section{öz}

Amaç: Araştırma, ebeveynlerin sağlık okuryazarlığı düzeyinin çocukluk dönemi aşılarına yönelik tutum ve davranışlarıyla ilişkisini belirlemek amacıyla yapıldı.

Gereç ve Yöntem: Tanımlayıcı tipte yapılan araştırma Kırıkkale ili merkez ilçesinde 0-12 aylık yaş grubunda çocuğu olan 279 ebeveynle yürütüldü. Örnekleminde lot kalite tekniği kullanıldı. Yazıı izin ve etik kurul onayı alındı. Araştırmanın verileri Tanımlayıcı Soru Formu ve Avrupa Sağlık Okuryazarlığı Ölçeği Türkçe Uyarlaması kullanılarak öz-bildirime dayalı toplandı. Verilerin analizinde tanımlayıcı istatistikler ve ki-kare kullanıldı.

Bulgular: Ebeveynlerin ortanca yaşının 30 (25-34) olduğu, annelerin $\% 45.1$ 'inin, babaların \%47.4'ünün üniversite ve sonrası eğitim düzeyine sahip olduğu belirlendi. Ebeveynlerin sağlık okuryazarlık puan ortalamasının $30.57 \pm 8.30$ olduğu, $\% 62.8$ 'inin genel sağlık okuryazarlık düzeyinin yetersiz ve sorunlu-sınırlı olduğu belirlendi. Ölçek puan ortalaması ile anne-baba olma durumu ve en uzun yaşanan yer arasındaki fark istatistiksel olarak anlamlı bulundu $(p<0.05)$. Ebeveynlerin \%98.6'sının çocuklarına aşı yaptırdığı belirlendi.

Sonuç: Ebeveynlerin sağlık okuryazarlık düzeyinin çocukluk dönemi aşılarına yönelik tutum ve davranışlarıyla ilişkisi olmadığı belirlendi. Anahtar kelimeler: Aşı, halk sağlığı hemşiresi, lot kalite tekniği, sağlık okuryazarlığı

\begin{abstract}
The Relationship of Parents' Health Literacy Level with Attitudes and Behaviors Towards Childhood Vaccines

Aim: The research was conducted to determine the relationship of parents' health literacy level with their attitudes and behaviors towards childhood vaccines.

Material and Methods: This descriptive study was conducted with 279 parents with children in the age group of 0-12 months in the Central District of Kırıkkale province. Lot quality technique was used in the sampling. Written permission and ethics committee approval were obtained. The data were collected based on self-reporting using the Descriptive Questionnaire and the Turkish version of the European Health Literacy Scale. Descriptive statistical tests and ChiSquare were used in the analysis of the data.

Results: The median age of the parents was 30 years (25-34), with $45.1 \%$ of the mothers and $47.4 \%$ of the fathers had a university and postgraduate education level. It was determined that the average health literacy score of parents was $30.57 \pm 8.30$ and that the overall health literacy level of $62.8 \%$ was insufficient and problematiclimited. The difference between the average scale score and the state of being a parent and the longest living place was found statistically significant $(p<0.05)$. It was found that $98.6 \%$ of parents had their children vaccinated.

Conclusion: It was determined that parents' level of health literacy was not related to their attitudes and behaviors towards childhood vaccines.

Keywords: Health literacy, lot quality technique, public health nurse, vaccine
\end{abstract}

\footnotetext{
${ }^{1}$ Öğr. Gör., Başkent Üniversitesi, Sağlık Hizmetleri Meslek Yüksekokulu, Illk ve Acil Yardım Programı, Ankara, Türkiye, E-posta: bertugrul@baskent.edu.tr, Tel: +90 531 640 30 46, ORCID: 0000-0003-2787-0869

${ }^{2}$ Doç. Dr., Kırıkkale Üniversitesi, Sağlık Bilimleri Fakültesi, Halk Sağlığı Hemşireliği Anabilim Dalı, Kırıkkale, Türkiye, E-posta: sevilalbayrak@kku.edu.tr, Tel: +90 31835737 38, ORCID: 0000-0001-9787-5716

Geliş Tarihi: 04 Temmuz 2020, Kabul Tarihi: 30 Mart 2021

*Bu araştırma, yüksek lisans tezinden üretilmiştir.

**Bu araştırma, 26-30 Kasım 2019 tarihlerinde gerçekleştirilen 3. Uluslararası 21. Ulusal Halk Sağlığı Kongresi'nde sözel bildiri olarak sunulmuştur.

Atıf/Citation: Ertuğrul B, Albayrak S. Ebeveynlerin Sağlık Okuryazarlığı Düzeyinin Çocukluk Dönemi Aşılarına Yönelik Tutum ve Davranışlarıyla İlişkisi. Hacettepe Üniversitesi Hemşirelik Fakültesi Dergisi 2021;8(2):186-195. DOI: 10.31125/hunhemsire.966461
} 


\section{GiRiş}

Sağlıkta sosyal eşitsizliklerin merkezinde yer alan okuryazarlığın, sağlık sistemlerinde çok az dikkate alınmasına rağmen ${ }^{1}$, sağlık sisteminin giderek daha karmaşık hale gelmesiyle birlikte önemi artmaktadır. Sağlık okuryazarlığının da sağlık hizmeti alan kişilerin bu sistemi etkin kullanabilmesi ve toplum sağlığının gelişmesine katkı sağlaması gibi nedenlerden dolayı önemi artmaktadır².

Sağlık okuryazarlığı başlangıçta klinik çalışmaların odak noktasıyken giderek toplum temelli sağlık araştırmalarında kullanılmaya başlanmıştır ${ }^{3}$. Yapılan çalışmalar, düşük sağlık okuryazarlığı olan kişilerin, doktorun talimatlarını ve tavsiyelerini veya sağlık eğitimini ve tanıtım materyallerini anlamada zorluk yaşadığını, bağışıklama hakkında da yeterli bilgiye sahip olmayabileceklerini göstermektedir ${ }^{4}$.

Sağlık okuryazarlığı bireyin kendisinin ve çocuklarının hastalıklardan korunmasında önemli rol oynamaktadır. Bireylerin hastalanmadan önce hastalıklara karşı bağışık hale gelmesi için aşı olması gerekmektedir. Aşılar 20. yüzyılın en büyük halk sağlığı başarılarından biri olarak kabul edilmektedir. Ülkemizde olduğu gibi dünyada da çiçek hastalığının ortadan kaldırılmasında ve çocuk felci, kızamık, kızamıkçık ve diğer bulaşıcı hastalıkların kontrol edilmesinde etkin rol almıştır 5 . Aşılama, çocuklarda bağışıklamayı sağlayarak dünya çapında bulaşıcı hastalıkların mortalite ve morbidite insidansını önemli ölçüde azaltmıştır. Avustralya'da çocukluk dönemi aşı alımı, son 5 yılda \%92.9'a ulaşan kapsamı ile yüksek seviyededir ${ }^{6}$. Ekonomi Kalkınma ve İşbirliği Örgütü ülkeleri genelinde bir yaşındaki çocukların \%95'i 3 doz kombine difteri, tetanoz ve boğmaca aşısı almıştır?.

Hastalığın önlenmesi ve ortadan kaldırılmasındaki etkinliğine rağmen, birçok ülkede rutin çocukluk çağı aşısı yaptırma alışkanlığı düşüktür ${ }^{8}$. Ebeveynlerin aşıları reddetme kararları, dünyanın birçok yerinde önemli bir halk sağlığı sorunudur.

Düşük aşı kapsamındaki alanların, çoğu zaman belirli coğrafi konumlarda kümelenmesi halk sağlığı için uygulama ve politika kaygıları yaratmaktadır ${ }^{9}$. Son yıllarda aşılara karşı gelişen şüphe aşı ile önlenebilir hastalıkların, salgınların ve ölümlerin devam etmesine neden olmaktadır ${ }^{10}$. Aşılamaya olan güvenin artmasına yardımcı olmak ve aşıya karşı yanlış inanışın önüne geçmek için, bireylerin aşıya olan tutumları ile içinde bulundukları geniş demografik ve psikososyal özellikler arasındaki ilişkinin daha iyi anlaşııması gerekmektedir ${ }^{11,12}$.

Ebeveynlerin çocuklarını bağışıklama ve aşılama kararlarını etkileme noktasında halk sağlığı hemşireleri aktif rol almaktadır. Halk sağlığı hemşirelerinin ebeveynlerle iletişim kurmak, ebeveynleri hastalıkların riskleri ve aşıların yan etkileri hakkında bilgilendirmek gibi görevleri bulunmaktadır. Halk sağığı hemşireleri aşıların güvenilirliği ile ilgili ebeveynlerin kaygılarını değerlendirme ve aşı yaptırmanın önündeki engelleri ortadan kaldırmada önemli rol oynar. Güvenilir sağlık hizmetinin sağlayıcıları olan halk sağlığı hemşireleri, ebeveynlerin çocuklarına bağışıklık kazandırma kararlarını etkileyerek salgınları önlemeye yardımcı olabilmektedir ${ }^{13}$.
Halk sağlığı hemşireliği alanında doğrudan ebeveynlerin sağlık okuryazarlık düzeyleriyle çocukluk dönemi aşılarına yönelik tutum ve davranışları arasındaki ilişkiyi değerlendiren araştırmalara rastlanmamıştır.

Araştırmanın Amacı

$\mathrm{Bu}$ araştırma, 0-12 ay yaş grubunda çocuğu olan ebeveynlerin sağlık okuryazarlığı düzeyinin çocukluk dönemi aşılarına yönelik tutum ve davranışlarıyla olan ilişkisini tespit etmek amacıyla yapılmıştır.

Bu araştırmada aşağıdaki sorulara yanıt aranmıştır.

1. Ebeveynlerin aşı tutum ve davranışları nelerdir?

2. Ebeveynlerin sağlık okuryazarlığı düzeyi nasıldır?

3.Ebeveynlerin sosyo-demografik özellikleri ve aşılara yönelik tutum ve davranışları ile sağlık okuryazarlığı düzeyleri arasında ilişki var mıdır?

\section{GEREÇ ve YÖNTEM \\ Araştırmanın Türü}

Bu araştırma tanımlayıc tipte yapılmıştır. Kırıkkale ili merkez ilçesine bağlı mahallelerde 11-31 Ocak 2019 tarihinde yapılmıştır.

\section{Araştırma Evren ve Örneklemi}

Araştırmanın evrenini Kırıkkale ili merkez ilçesine bağlı 31 mahallede ikamet eden 0-12 ay yaş grubu 2599 çocuğun ebeveynleri oluşturmaktadır. Aşılama hizmetlerinin toplum üzerindeki etkisinin tespiti ve saha çalışmaları için kullanılan lot kalite tekniği (LKT) sayesinde bölgedeki küçük yerleşim yerleri ve araştırma yapılan tüm nüfus içerisindeki farklı yerlerin karşılaştırılması yapılabilmektedir. Ayrıca aşılama faaliyetlerinin etkinlikleri ve bölgesel haritaları çıkarılabilmektedir ${ }^{14}$. Araştırmada optimum örneklem büyüklüğü, Dünya Sağlık Örgütü'nün (DSÖ) Genişletilmiş Bağışıklama Programı araştırmalarında, LKT'nin saha uygulamaları için geliştirdiği güven aralığı ve güvenilirlik düzeyine göre belirlenmiştir ${ }^{14}$. Araştırma için güven aralığı $\pm \% 7$ ve güvenilirlik düzeyi $\% 95$ seçilerek, DSÖ’nün geliştirdiği tablodan örneklem büyüklüğü 196 kişi bulunmuştur (Tablo 1). Örneklem büyüklüğü belirlenirken hedeflenen nüfusun $\% 10$ 'undan daha büyük bir oran belirlenemez. Hesaplama sonucunda \%10'un üzerinde bir değer tespit edilmesi halinde örneklem büyüklüğünün azaltılması gerekmektedir. Örneklem oranı örneklem büyüklüğünün hedef nüfusa oranı olan 196/2599=\%7.5 olarak bulunmuştur. Her mahalle bir lot kabul edilerek toplam 31 lot üzerinde çalışılmıştır. En az lot örneklem büyüklüğü genel örneklem büyüklüğünün lot sayısına oranı olup 196/31=6.3 kişi bulunmuş bir üst sayıya yuvarlanarak 7 kişi olarak tespit edilmiş ve her lotta 9 ebeveyn değerlendirilmiştir. Böylece her lot bölgesinden 9 kişi olmak üzere 31 lot bölgesinde 0-12 ay yaş grubu 279 çocuğun ebeveynleri araştırmanın örneklemini oluşturmuştur (Tablo 1). 
Tablo 1. LKT Genel Örneklem Büyüklüğü Belirleme Tablosu ${ }^{14}$

\begin{tabular}{|c|c|c|c|}
\hline \multirow{2}{*}{$\begin{array}{c}\text { İstenilen } \\
\text { güven } \\
\text { aralığı } \\
\end{array}$} & \multicolumn{3}{|c|}{ İstenilen güvenirlik düzeyi } \\
\hline & $\% 90$ & $\% 95$ & $\% 99$ \\
\hline $\pm 1 \%$ & 6718 & 9512 & 16317 \\
\hline $\pm 2 \%$ & 1688 & 2395 & 4130 \\
\hline $\pm 3 \%$ & 751 & 1066 & 1840 \\
\hline $\pm 4 \%$ & 423 & 600 & 1036 \\
\hline $\pm 5 \%$ & 270 & 384 & 663 \\
\hline $\pm 6 \%$ & 188 & 267 & 461 \\
\hline $\pm 7 \%$ & 138 & 196 & 338 \\
\hline $\pm 8 \%$ & 106 & 150 & 259 \\
\hline $\pm 9 \%$ & 83 & 119 & 205 \\
\hline $\pm 10 \%$ & 68 & 96 & 166 \\
\hline
\end{tabular}

Veri Toplama Araçları

Araştırmanın verileri, araştırmacılar tarafından oluşturulan Tanımlayıcı Soru Formu ${ }^{15}$ ve Avrupa Sağlık Okuryazarlığı Ölçeği Türkçe Uyarlaması (ASOY-TR) Formu ${ }^{16}$ kullanılarak toplanmıştır. Tanımlayıc Soru Formu, katılımcıların sosyodemografik özellikleri ve aşı yaptırıp/yaptırmamaya karşı görüşleri, aşılar hakkında bilgiyi öğrendiği yer ve kişi, aşılar hakkında bilgi ve tutumları ile ilgili 33 yapılandırılmış sorudan oluşmaktadır. ASOY, 2012 yılında Avrupa Sağlık Okuryazarlığı Araştırma Konsorsiyumu tarafından geliştirilmiştir. ASOY'un Türkçe'ye uyarlanmış hali olan ASOY-TR'nin Türkiye'de geçerlilik ve güvenilirlik çalışması Abacıgil, Harlak ve Okyay tarafından 2016 yılında yapılmıştır. 47 sorudan oluşan bu ölçek, 4 dereceli olup her madde 1=çok zor, 2=zor, 3=kolay, 4=çok kolay olarak belirlenmiştir. Ölçekten alınan puanlar 4 kategoride değerlendirilmiştir: (025) puan: yetersiz sağlık okuryazarlık, (>25-33): sorunlu sınırlı sağlık okuryazarlık, (>33-42): yeterli sağlık okuryazarlık, (>42-50): mükemmel sağlık okuryazarlık olarak belirlenmiştir. Ölçeğin cronbach alpha değeri sırasıyla; Tedavi ve Hizmet Boyutu için 0.86, Hastalıklardan Korunma Boyutu için 0.87, Sağlığın Geliştirilmesi Boyutu için 0.91 ve genel sağlık okuryazarlığı için 0.95 olarak bulunmuştur. Bu araştırmada ise ölçeğin cronbach alpha değerleri sırasıyla, Tedavi ve Hizmet Boyutu için 0.90, Hastalıklardan Korunma Boyutu için 0.87, Sağığın Geliştirilmesi Boyutu için 0.90 ve genel sağlık okuryazarlığı için de 0.95 bulunmuştur.

\section{Verilerin Toplama Araçlarının Uygulanması}

Araştırmada veriler, Kırıkkale ili merkez ilçesindeki mahallerin her biri bir lot bölgesi kabul edilerek 31 lottaki 012 ay yaş grubu çocuğa sahip ebeveynlere veri toplama araçları uygulanarak elde edilmiştir. Araştırmacı ve araştırmacı tarafından anketin uygulanması sırasında dikkat edilecek konular hakkında bir saat eğitim verilen anketörler, araştırmayı kabul eden ebeveynlerle yüz yüze görüşerek veri toplama işlemini gerçekleştirmiştir. Veri toplamada bireylerin yaşadığı ortamda değerlendirilmesi ve evrenin büyük olduğu araştırmalarda kullanılan rastlantısal güzergâh örnekleme yöntemi kullanılmış ve ilk evi belirlemek için her mahallenin muhtarıyla görüşülmüştür. Muhtarlığa en yakın evden başlayarak gerekli lot sayısına ulaşılmıştır.

\section{Verilerin Değerlendirilmesi}

Veriler, SPSS for Windows 17 paket programı ile analiz edilmiştir. Örneklem sayısı 30'dan büyük olduğu için Kolmogorov-Smirnov testi yapılmış, bağımsız değişkenlerin normal dağılıma uygun olmadığı, ASOY-TR ve alt boyut puanlarının normal dağıldığı belirlenmiştir. Verilerin analizinde sayı, yüzde, en düşük ve en yüksek değer, ortalama, ortanca (\%25 ve \%75 çeyrek) ve bağımsız değişkenler ile kategorik verilerin karşılaştırı masında ki kare testi kullanılarak istatistiksel analizler yapılmış, anlamlılık düzeyi $p<0.05$ olarak kabul edilmiştir.

\section{Araştırmanın Etik Boyutu}

Araştırmanın etik kurallara uygunluğu açısından Kırıkkale Üniversitesi Girişimsel Olmayan Araştırmalar Etik Kurulundan 24.10.2018 tarihli 2018.10.13 karar numarasıyla onay alınmıştır. Veri toplamak için Kırıkkale il Sağlık Müdürlüğü'nden 11.01.2019 tarihli 46743357-799 sayılı izin alınmıştır. ASOY Türkçe Uyarlamasını kullanmak için Filiz Abacıgil'den elektronik posta yoluyla izin alınmıştır. Araştırmada Helsinki Deklerasyonu Prensipleri'ne uygunluk ilkesi yerine getilmiştir. Katılımcılardan "Bilgilendirilmiş Onam İlkesi", "Gönüllülük İlkesi" ve "Gizlilik Illkesi" yerine getirilerek yazılı onam alınmıştır. Araştırma ve Yayın Etiği'ne uyulmuştur.

\section{Araştırmanın Sınırlılıkları}

Araştırma 12 ay ve altında çocuğa sahip olan ve veri toplama sırasında evde bulunan gönüllü ebeveynlerle yürütülmüştür.

\section{BULGULAR}

Araştırmaya katılan 279 ebeveynin ortanca yaşı 30 (25-34), ortanca çocuk sayısı 2 (1-2) olarak belirlenmiştir. Ebeveynlerin sahip oldukları bebeklerin ortanca yaşı 8 (4-12) ay olarak bulunmuştur (Tablo 2).

Tablo 2. Ebeveynlerin ve Çocukların Demografik Özellikleri $(\mathrm{n}=\mathbf{2 7 9 )}$

\begin{tabular}{|l|c|c|c|}
\hline $\begin{array}{l}\text { Demografik } \\
\text { Özellikler }\end{array}$ & $\mathbf{n}$ & $\begin{array}{c}\text { X } \pm \text { SS } \\
\text { (en az-en çok) }\end{array}$ & $\begin{array}{c}\text { Ortanca } \\
\text { (\%25-\%75 } \\
\text { çeyrek) }\end{array}$ \\
\hline Yaş & 279 & $30.18 \pm 6.16(19-58)$ & $30(25-34)$ \\
\hline Çocuk sayısı & 279 & $1.74 \pm 0.83(1-4)$ & $2(1-2)$ \\
\hline $\begin{array}{l}\text { Çocuğun yaşı } \\
\text { (ay) }\end{array}$ & 279 & $7.79+3.74(1-12)$ & $8(4-12)$ \\
\hline
\end{tabular}

$\mathrm{X} \pm \mathrm{SS}$ : Ortalama, standart sapma

Kırıkkale ili Merkez ilçesine bağı mahallelerde ikamet eden ebeveynlerin \%62.8'inin genel sağlık okuryazarlık düzeyinin yetersiz ve sorunlu-sınırlı olduğu belirlendi. Ebeveynlerin genel sağlık okuryazarlığı puan ortalamalarına göre Yenimahalle, Yaylacık, Ovacık, Yenidoğan, Gürler, Gündoğdu, Yuva ve Çullu mahallelerinde yaşayan ebeveynlerin sağlık okuryazarlık düzeyleri yeterli olarak tespit edilmiştir. Diğer mahallelerde ikamet eden ebeveynlerin ise sağlık okuryazarlık düzeylerinin sorunlusınırlı olduğu bulunmuştur (Şekil 1).

Araştırmaya katılan ebeveynlerin ASOY-TR Tedavi ve Hizmet Alt Boyutu puan ortalaması 31.91 \pm 8.90 , Hastalıklardan Korunma Alt Boyutu puan ortalaması 30.34 \pm 9.16 , Sağlığı Geliştirme Alt Boyutu puan ortalaması $29.44 \pm 9.48$ ve genel sağlık okuryazarlığı toplam puan ortalaması $30.57 \pm 8.30$ olarak tespit edilmiştir. Ebeveynlerin genel sağlık okuryazarlık düzeylerinin sorunlu-sınırlı olduğu görülmektedir (Tablo 3). 


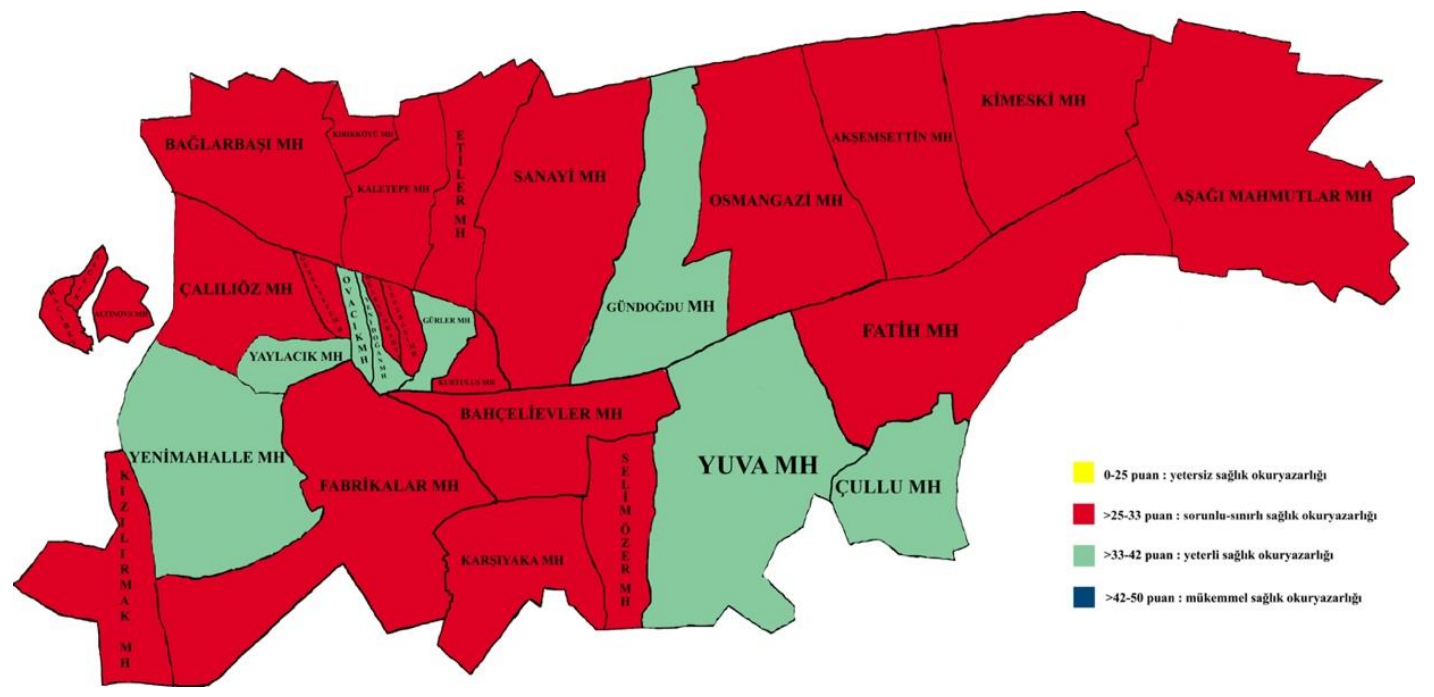

Şekil 1. Sağlık Okuryazarlık Düzeylerinin Dağılımı

Tablo 3. ASOY-TR ve Alt Boyutlarından Alınan Puan Ortalamalarının Dağııımı ( $\mathrm{n=279)}$

\begin{tabular}{|l|c|c|c|}
\hline & N & $\begin{array}{c}\text { En az- } \\
\text { En çok }\end{array}$ & $\begin{array}{c}\text { Ortalama } \pm \text { Standart } \\
\text { sapma }\end{array}$ \\
\hline $\begin{array}{l}\text { Tedavi ve } \\
\text { hizmet }\end{array}$ & 279 & $\begin{array}{c}2.08- \\
50.00\end{array}$ & $31.91 \pm 8.90$ \\
\hline $\begin{array}{l}\text { Hastalıklardan } \\
\text { korunma }\end{array}$ & 279 & $\begin{array}{l}0.00- \\
50.00\end{array}$ & $30.34 \pm 9.16$ \\
\hline $\begin{array}{l}\text { Sağlığı } \\
\text { geliştirme }\end{array}$ & 279 & $\begin{array}{l}0.00- \\
50.00\end{array}$ & $29.44 \pm 9.48$ \\
\hline Genel & 279 & $\begin{array}{l}2.13- \\
50.00\end{array}$ & $30.57 \pm 8.30$ \\
\hline
\end{tabular}

Ebeveynlerin \%98.6'sının çocuklarına aşı yaptırdı̆̆ı belirlenmiştir. Bu araştırmada Kırıkkale ili Merkez ilçesine bağlı 4 mahallede bazı ebeveynlerin çocuklarını aşılatmadığı tespit edilmiştir. Bunlar; Hüseyin Kahya, Bahçelievler, Karşıyaka ve Yuva Mahalleleri'dir. Geri kalan tüm mahallelerde tam aşılamanın sağlandığı tespit edilmiştir (Şekil 2).

Ebeveynlerin \%74.6'sı bebeklerinin sağlığı ve aşılama durumları hakkında eşleriyle birlikte karar verdiklerini belirtmiştir. Ebeveynlerin \%75.3'ünün aşılar hakkında bilgiyi doktordan aldığı, \%56.3'ünün ise ebe/hemşireden aldığı belirlenmiştir. Ebeveynlerin \%93.2'si bebeklerinin aşısının aile hekimliğinde yapıldığını ve $\% 61.6$ 'sı bebeklerinin aşı sonrasında herhangi bir yan etki yaşamadığını belirtmiştir. Ebeveynlerin yarıdan fazlası (\%57.7) rutin aşıların hastalık durumunda ertelenebileceğini ifade ederken \%38'i ise ateş durumunda ertelenebileceğini ifade etmiştir. Ebeveynlerin \%98.6'sı çocuklarına aşı yaptırdığını, \%95.3'ü ise aşı yaptırmanın gerekli olduğunu belirtmiştir (Tablo 4).
Tablo 4. Ebeveynlerin Aşılarla ilgili Davranış Özelliklerinin Dağııımı

\begin{tabular}{|c|c|c|}
\hline Davranış özellikleri & $n$ & $\%$ \\
\hline \multicolumn{3}{|c|}{ Çocuğun sağılı̆ıyla ilgili ve aşılar konusunda kararları veren ebeveyn } \\
\hline Anne & 68 & 24.4 \\
\hline Baba & 4 & 1.4 \\
\hline Anne ve baba birlikte & 207 & 74.2 \\
\hline \multicolumn{3}{|c|}{ Aşılar hakkında bilginin öğrenildiği yer/Kişi* } \\
\hline Doktor & 210 & 75.3 \\
\hline Ebe/Hemşire & 157 & 56.3 \\
\hline TV, radyo, gazete & 37 & 13.3 \\
\hline Internet & 63 & 22.6 \\
\hline Komşular/Akrabalar & 11 & 8.6 \\
\hline \multicolumn{3}{|l|}{ Aşıların yaptıııldığı yer* } \\
\hline Bilmiyorum & 3 & 1.1 \\
\hline Aile hekimliği & 260 & 93.2 \\
\hline Hastane & 99 & 35.5 \\
\hline \multicolumn{3}{|c|}{ Aşı kaynaklı yan etki yaşama } \\
\hline Evet & 103 & 36.9 \\
\hline Hayır & 172 & 61.6 \\
\hline Aşı yaptırmadım & 4 & 1.5 \\
\hline \multicolumn{3}{|c|}{ Rutin aşıların ertelenebilme durumu* } \\
\hline Hastalık & 161 & 57.7 \\
\hline Ateş & 106 & 38.0 \\
\hline Ertelenemez & 17 & 6.1 \\
\hline Bilmiyorum & 63 & 22.6 \\
\hline \multicolumn{3}{|c|}{ Çocuklara aşı yaptırma durumu } \\
\hline Evet & 275 & 98.6 \\
\hline Hayır & 4 & 1.4 \\
\hline \multicolumn{3}{|c|}{ Aşı yaptırmanın gerekli olduğunu düşünme } \\
\hline Evet & 266 & 95.3 \\
\hline Hayır & 13 & 4.7 \\
\hline
\end{tabular}




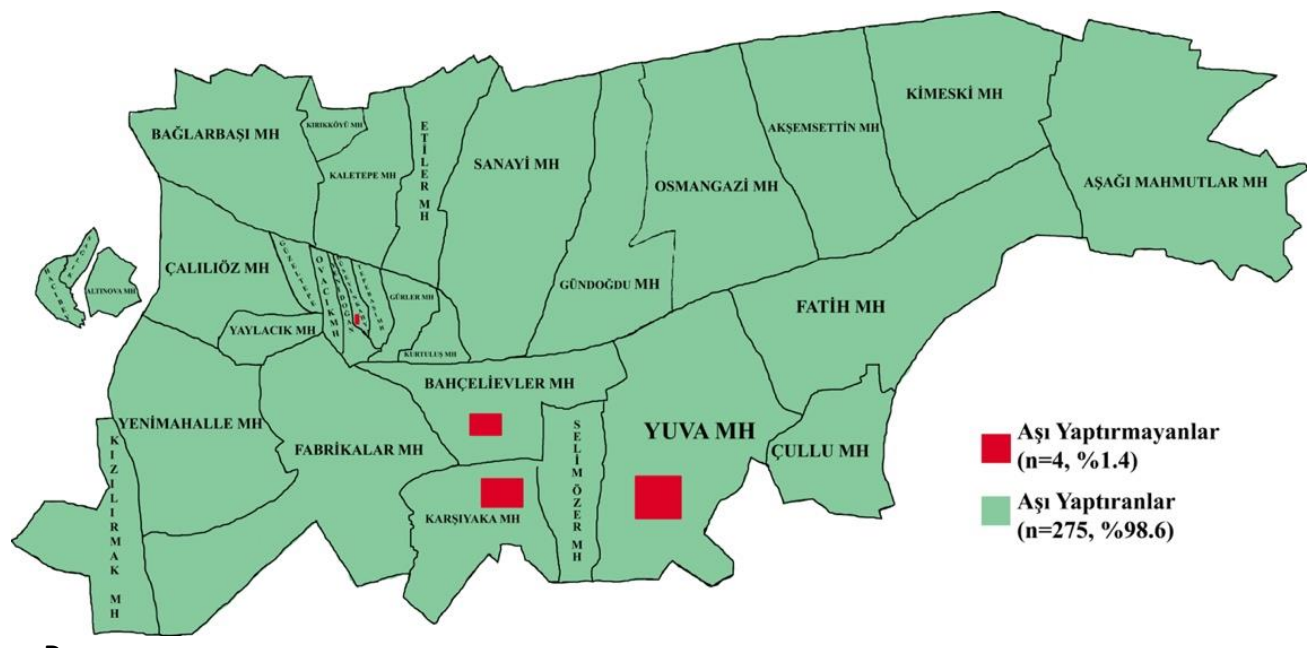

Şekil 2. Aşılanma Durumu

Ebeveynlerden annelerin \%34.3'ünün, babaların ise \%47.8'inin sorunlu-sınırlı düzeyde sağlık okuryazarlığına sahip olduğu tespit edilmiştir. Ebeveynlerden babaların sorunlu-sınırlı sağlık okuryazarlık düzeyi annelere oranla daha yüksektir. ( $\left.\chi^{2}=8.441 ; p=0.038\right)$ (Tablo 5).

Ebeveynlerden 15-24 yaş grubunda olanların \%36.7'sinin sağlık okuryazarlık düzeyi yeterli iken 25-34 yaş grubundakilerin \%33.3'ünün, 35 yaş ve üzeri ebeveynlerin $\% 50.8^{\prime}$ inin sağlık okuryazarlık düzeyinin sorunlu-sınırlı olduğu tespit edilmiştir. Ebeveynlerin yaşı ile sağlık okuryazarlık düzeyleri arasındaki fark istatistiksel olarak anlamlı bulunmamıştır ( $\left.\chi^{2}=11.086 ; p=0.086\right)$ (Tablo 5).

Annelerin sağlık okuryazarlık düzeyi ilköğretim mezunu olanların \%36.4'ünün, lise mezunlarının \%37.9'unun, üniversite ve sonrası eğitim seviyesinde olanların \%35.7'sinin sorunlu-sınırlı düzeyde olduğu tespit edilmiştir. Babaların da ilköğretim mezunu olanların \%38.6'sının sağlık okuryazarlık düzeyi yeterli iken lise mezunlarının \%38.8'inin, üniversite ve sonrası eğitim seviyesinde olanların \%37.9'unun sağlık okuryazarlık düzeyinin sorunlu-sınırlı olduğu tespit edilmiştir. Anne ve babanın eğitimi ile sağlık okuryazarlık düzeyleri arasındaki fark istatistiksel olarak anlamlı bulunmamıştır (sırasıyla $\chi^{2}=7.435 ; \quad p=0.282$; $\chi^{2}=9.254 ; p=0.160$ ) (Tablo 5).

Ebeveynlerin aylık gelir durumu açısından sağlık okuryazarlık düzeyine bakıldığında geliri giderinden fazla olanların \%35.1'inin, geliri giderinden az olanların \%32.1'inin sağlık okuryazarlık düzeyi yeterli iken geliri giderine eşit olanların \%42.4'ünün sorunlu-sınırlı düzeyde olduğu tespit edilmiştir. Ailelerin aylık gelir durumları ile sağlık okuryazarlık düzeyleri arasındaki fark istatistiksel olarak anlamlı bulunmamıştır $\left(\chi^{2}=6.910 ; p=0.329\right)$ (Tablo 5).

Ebeveynlerin en uzun yaşadıkları yer ile sağılık okuryazarlık düzeyi arasındaki ilişki incelediğinde köy/kasabada yaşayanların \%50'sinin, kent merkezinde yaşayanların \%33.1'inin sağlık okuryazarlık düzeyi yetersiz iken büyükşehirde yaşayanların \%46.1'inin sağlık okuryazarlık düzeyi sorunlu-sınırlı olarak tespit edilmiştir. Ebeveynlerin en uzun süre yaşadıkları yer ile sağlık okuryazarlık düzeyleri arasındaki fark istatistiksel olarak anlamlı bulunmuştur $\left(\chi^{2}=26.126 ; \quad p=0.000\right)$. Farkın kaynağı incelendiğinde köy/kasabada yaşayanların yetersiz sağlık okuryazarlık oranının daha yüksek olduğu belirlenmiştir (Tablo 5).

Ebeveynlerin zorunlu aşılama programları hakkındaki düşüncesi incelendiğinde \%81.4'ü aşı yaptırmanın zorunlu olması gerektiğini düşünmektedir. Sağlık okuryazarlık düzeyi ile zorunlu aşılama programları hakkındaki düşünce arasındaki ilişki incelendiğinde sağlık okuryazarlık düzeyi sorunlu-sınırlı olan ebeveynlerin \%36.6'sı aşı yaptırmanın zorunlu olması gerektiğini, \%36.5' $i$ ise zorunlu olmaması gerektiğini ifade etmiştir. Ebeveynlerin sağlık okuryazarlık düzeyleri ile zorunlu aşılama programları hakkındaki düşünceleri arasındaki fark istatistiksel olarak anlamlı bulunmamıştır ( $\chi^{2}=0.334 ; p=0.953$ ) (Tablo 5 ).

Ebeveynlerin çocuklarına aşı yaptırma ve aşıların gerekli olduğunu düşünme durumları ile sağlık okuryazarlığı karşılaştırılmak istenmiştir. Ancak ebeveynlerden dördünün çocuğuna aşı yaptırmadığı ve 13 kişinin aşı yaptırmanın gereksiz olduğunu düşündüğü görüldüğü için istatistiksel bir değerlendirme yapılamamıştır. 
Tablo 5. Ebeveynlerin Sosyo-Demografik Özellikleri ve Aşı Yaptırma Düşünceleri ile Sağlık Okuryazarlığı Durumunun Karşılaştırılmașı ( $\mathbf{n = 2 7 9}$

\begin{tabular}{|c|c|c|c|c|c|c|c|}
\hline Değişkenler & n (\%) & $\begin{array}{l}\text { Yetersiz sağlık okuryazarlık } \\
\mathrm{n}(\%)\end{array}$ & $\begin{array}{l}\text { Sorunlu-sınırlı sağlık okuryazarlık } \\
\mathrm{n}(\%)\end{array}$ & $\begin{array}{l}\text { Yeterli sağlık okuryazarlık } \\
\mathrm{n}(\%)\end{array}$ & $\begin{array}{l}\text { Mükemmel sağlık okuryazarlık } \\
\text { n (\%) }\end{array}$ & $\mathbf{p}$ & $x^{2}$ \\
\hline \multicolumn{8}{|l|}{ Ebeveynlik durumu } \\
\hline Anne & $233(83.5)$ & $59(25.3)$ & $80(34.3)$ & $74(31.8)$ & $20(8.6)$ & \multirow[t]{2}{*}{$0.038^{*}$} & \multirow[t]{2}{*}{8.441} \\
\hline Baba & $46(16.5)$ & $14(30.4)$ & $22(47.8)$ & $5(10.9)$ & $5(10.9)$ & & \\
\hline \multicolumn{8}{|l|}{ Yaş } \\
\hline $15-24$ & $49(17.6)$ & $14(28.6)$ & $14(28.6)$ & $18(36.7)$ & $3(6.1)$ & \multirow[t]{3}{*}{0.086} & \multirow[t]{3}{*}{11.086} \\
\hline $25-34$ & $165(59.1)$ & $43(26.1)$ & $55(33.3)$ & 51 (30.9) & $16(9.7)$ & & \\
\hline $35+$ & $65(23.3)$ & $16(24.6)$ & $33(50.8)$ & $10(15.4)$ & $6(9.2)$ & & \\
\hline \multicolumn{8}{|l|}{ Anne eğitimi } \\
\hline İlköğretim & $66(23.7)$ & $22(33.3)$ & $24(36.4)$ & $18(27.3)$ & $2(3.0)$ & \multirow[t]{3}{*}{0.282} & \multirow[t]{3}{*}{7.435} \\
\hline Lise & $87(31.2)$ & $24(27.6)$ & $33(37.9)$ & $23(26.4)$ & $7(8.1)$ & & \\
\hline Üniversite ve sonrası & $126(45.1)$ & $27(21.4)$ & $45(35.7)$ & $38(30.2)$ & $16(12.7)$ & & \\
\hline \multicolumn{8}{|l|}{ Baba eğitimi } \\
\hline Ilköğretim & 44 (15.7) & $15(34.1)$ & $12(27.3)$ & $17(38.6)$ & $0(0.0)$ & \multirow[t]{3}{*}{0.160} & \multirow[t]{3}{*}{9.254} \\
\hline Lise & $103(36.9)$ & $26(25.2)$ & $40(38.8)$ & $26(25.2)$ & $11(10.8)$ & & \\
\hline Üniversite ve sonrası & $132(47.4)$ & $32(24.2)$ & 50 (37.9) & $36(27.3)$ & 14 (10.6) & & \\
\hline \multicolumn{8}{|l|}{ Gelir durumu } \\
\hline Gelir giderden az & $78(28.0)$ & $21(26.9)$ & $23(29.5)$ & $25(32.1)$ & 9 (11.5) & \multirow[t]{3}{*}{0.329} & \multirow[t]{3}{*}{6.910} \\
\hline Gelir gidere eşit & 144 (51.6) & $39(27.1)$ & $61(42.4)$ & 34 (23.6) & $10(6.9)$ & & \\
\hline Gelir giderden fazla & $57(20.4)$ & $13(22.8)$ & $18(31.6)$ & $20(35.1)$ & $6(10.5)$ & & \\
\hline \multicolumn{8}{|l|}{ En uzun yaşanan yer } \\
\hline Büyükşehir & $102(36.6)$ & $11(10.8)$ & $47(46.1)$ & $37(36.3)$ & $7(6.8)$ & \multirow{3}{*}{$0.000^{*}$} & \multirow{3}{*}{26.126} \\
\hline Kent merkezi & $157(56.3)$ & $52(33.1)$ & $49(31.2)$ & $39(24.8)$ & $17(10.9)$ & & \\
\hline Köy/Kasaba & $20(7.1)$ & $10(50.0)$ & $6(30.0)$ & $3(15.0)$ & $1(5.0)$ & & \\
\hline \multicolumn{8}{|c|}{ Zorunlu aşılama programı hakkında düşünce } \\
\hline Zorunlu olmalı & $227(81.4)$ & $58(25.6)$ & $83(36.6)$ & $65(28.6)$ & $21(9.2)$ & \multirow{2}{*}{0.953} & \multirow{2}{*}{0.334} \\
\hline Zorunlu olmamalı & $52(18.6)$ & $15(28.8)$ & $19(36.5)$ & $14(26.9)$ & $4(7.8)$ & & \\
\hline
\end{tabular}

* p<0.05 dešeri anlamidir, $x^{2}:$ Ki Kare Testi. 


\section{TARTIŞMA}

Ebeveynlerin sağlık okuryazarlığı düzeyinin çocukluk dönemi aşılarına yönelik tutum ve davranışlarıyla olan ilişkisini tespit etmek amacıyla yürütülen araştırma bulguları, araştırma soruları ve literatürden elde edilen bilgiler doğrultusunda tartışılmıştır. Bu araştırmada ebeveynlerin ASOY-TR genel sağlık okuryazarlık puan ortalamasının $30.57 \pm 8.30$ olduğu görülmüştür. Avrupa genelinde yapılan bir araştırma sonucunda Avrupa genel sağıık okuryazarlığı ortalaması 33.8 \pm 7.95 olarak bulunmuştur. Bu ülkeler içerisinde Hollanda, İrlanda, Almanya ve Polonya gibi bazı Avrupa ülkelerinde genel sağlık okuryazarlık düzeylerinin ortalamanın da üzerinde olduğu belirlenmiştir ${ }^{17}$. Yurt içerisinde yapılan 23 ili kapsayan bir araştırmada Türkiye geneli sağlık okuryazarlık ortalaması $30.4 \pm 0.16$ olarak bulunmuştur $^{18}$. Avrupa'nın sağlık okuryazarlık düzeyinin Türkiye'nin üzerinde olduğu görülmektedir.

$\mathrm{Bu}$ araştırmada ebeveynlerden annelerin babalara oranla sağlık okuryazarlık düzeyi puanı daha yüksek olup fark istatistiksel olarak anlamlıdır $(p=0.038)$. Çatı, Karagöz, Yalman ve Öcel'in (2018) yaptığı bir araştırmada cinsiyet ile sağlık okuryazarlığı arasındaki fark istatistiksel olarak anlamlı bulunmamıştır ${ }^{19}$. Öncü vd. (2018) yaptığı bir başka araştırmada erkeklerin kadınlara oranla sağlık okuryazarlık düzeyinin daha yüksek olduğu tespit edilmiştir $(p<0.05)^{20}$. Yapılan araştırmalarda sağlık okuryazarlığının cinsiyetten etkilenmesi ile ilgili farklı sonuçlar elde edilmiştir. Ancak araştırmalar incelendiğinde bu araştırmadaki annelerin eğitim düzeyinin diğer araştırmalara göre daha yüksek olduğu görülmüştür.

Yaş arttıkça sağlık okuryazarlığı düzeyinin azaldığını gösteren çalışmalar oldukça fazladır $16,17,21,22$. Özellikle Avrupa'daki yapılan araştırmalarda 66 ile 75 yaş arasındaki bireylerin \%51,8'inin sınırlı sağlık okuryazarlık düzeyine sahip olduğu görülmektedir ${ }^{17,23}$. Buna karşın literatür taramalarında yaş ile sağlık okuryazarlık düzeyleri arasında herhangi bir farkın olmadığı çalışmaya da rastlanmıştır ${ }^{24}$. Bu araştırmaya katılan ebeveynlerin yaşı ile sağlık okuryazarlık düzeyleri arasında anlamlı bir farkın olmadığı tespit edilmiştir $(p=0.086)$. Yapılan araştırmalar arasındaki farklıı̆̆ın kaynağına bakıldığında, bu araştırmaya katılan bireylerin yaş gruplarının dağılımlarının birbirine yakın olmasından ve ileri yaş grubunu temsil eden örneklemin az olmasından kaynaklanabileceği düşünülebilir.

$\mathrm{Bu}$ araştırmada anne ve baba eğitim durumu ile sağlık okuryazarlık düzeyleri arasında anlamlı bir fark bulunmamıştır (sırasıyla $p=0.282$ ve $p=0.160$ ). Literatür taramalarında düşük eğitim seviyeleri ile düşük sağlık sonuçları arasında güçlü bir bağ olduğu görülmektedir ${ }^{21}$. Özellikle eğitim seviyesinin düşüklüğü ekonomik kaynakların az kullanılmasına, sağlık hizmetlerine erişim noktasında sorunların yaşanmasına, sosyal destek eksikliğine ve istenmeyen sağlık davranışlarına neden olmaktadır. ABD'de yapılan bir çalışmada bireylerin eğitim durumu ile sağlık okuryazarlık düzeyleri arasında pozitif ve anlamlı bir ilişki olduğu tespit edilmiştir $(p<0.01)^{25}$. Yurt içinde yapılan bir başka çalışmada eğitim seviyesi yüksek olan bireylerin sağlık okuryazarlığının yüksek olduğu tespit edilmiştir $(p<0.05)^{16}$.
Bu araştırmaya katılan anne ve babaların eğitim seviyelerinin oldukça yüksek olması sebebiyle yapılan diğer araştırmalarla farklılı̆ın ortaya çıktığı düşünülmektedir.

Bu araştırmada büyükşehir ve kent merkezinde daha uzun süre yaşayanların köy/kasabada yaşayanlara oranla sağlık okuryazarlık düzeylerinin yüksek olduğu görülmüştür $(p=0.00)$. Bu araştırma sonuçlarına benzer olarak yapılan çalışmalarda kırsal kesimde yaşayanların kentte yaşayanlara göre sağlık okuryazarlığının daha düşük olduğu görülmüştür26,27.

Sağlık okuryazarlığı ebeveynlerin aşı tercihlerinin ölçülmesi açısından son derece önemlidir. Ölçüm tercihleri genellikle ebeveynlerin aşılar hakkında risk bilgilerini yorumlamasını ve değerlendirmesini gerektirir.

Önceki araştırmalar düşük eğitim seviyesi ve düşük sağlık okuryazarlığı olan bireylerin aşılar hakkındaki bilgileri istemede güçlük yaşadıklarını göstermektedir ${ }^{28,29}$. Araştırmada ebeveynlerin \%98.6'sının çocuklarını aşılattığı görülmüştür. Aşılar tüm dünyada kullanılan koruyuculuğu yüksek, maliyeti düşük ve bulaşıcı hastalıklarla mücadele kapsamında kullanılan en etkin halk sağlığı uygulamalarının başında gelmektedir. ABD Hastalık Kontrol ve Korunma Merkezinin (2017) 19-35 aylık çocuklar üzerinde yapmış olduğu araştırmada aşılama oranının \%90'ın üzerinde olduğu görülmektedir ${ }^{30}$. Avustralya Hükümeti Sağlık Departmanı (2018) verilerine göre ülke genelinde bir yaş ve altı çocukların aşılama oranı \%94.1 olarak belirtilmiştir ${ }^{31}$. Türkiye'de Taşar ve Dallar (2015) yapmış olduğu çalışmada aşılama oranlarının $\% 90$ 'ın üzerinde olduğu görülmektedir ${ }^{32}$. Türkiye Nüfus ve Sağlık Araştırmaları (2018) verilerine göre Türkiye'de $12-23$ ay yaş grubunda bulunan çocukların \%67'sinin yaşa uygun tam aşılı olduğu tespit edilmiştir ${ }^{33}$.

$\mathrm{Bu}$ araştırma sonuçlarına göre Kırıkkale ilindeki aşılatma oranı yapılan çalışmalarda gösterilenden daha yüksektir. Avrupa ülkelerinde aşılama oranının gelişmemiş ülkelerdeki aşılama oranından yüksek olduğu görülmüştür. Bu araştırmada aşılama oranının yüksek çıkmasının nedeninin aşıların tamamlanmamış olması ve ebeveynlerin aşıya güvenmelerinden kaynaklandığı düşünülebilir.

Bu araştırmada ebeveynlerin \%75.3'ü aşılar hakkındaki bilgiyi doktordan, \%56.3'ü ise hemşire/ebeden aldığını ifade etmişlerdir. Üst solunum yolu enfeksiyonu geçiren çocukların ailelerinin influenza aşısı hakkındaki düşüncelerinin belirlendiği bir çalışmada ebeveynlerin \%59.7'si aşılar hakkında bilgiyi doktordan aldıklarını belirtmiştir ${ }^{34}$. Yapılan çalışmalarda araştırmamızla benzer sonuçlar bulunmuş olup aşılar hakkında bilginin doktor ve hemşirelerden alındığı belirtilmiştir.

Bu araştırmada ebeveynlerin \%93.2'si çocuklarına aşıyı aile hekimliğinde yaptırdığını ifade etmiştir. Kürtüncü, Alkan, Bahadır ve Arslan'ın (2017) Zonguldak ilinde yaptığı bir çalışmada annelerin \%94.4'ü, Taşar ve Dallar'ın (2015) yaptığı bir başka çalışmada ise katılımcıların \%90.2'si aşıların yapıldığı yer olarak aile hekimliğini belirtmiştir ${ }^{32,35}$. Yurt içerisinde yapılan diğer çalışmalarla benzer şekilde ebeveynler aşılama konusunda aile sağlığı merkezlerini tercih etmektedir. Temel sağlık hizmetlerinin aile sağlığı merkezlerinde verildiği ülkemizde bu durumun ebeveynler 
tarafından doğru algılandığı görülmektedir. Aile hekimliklerinde aşıların uygulanması ve takibinin yapılması ebe ya da hemşirelere aittir. Ebeveynlerin ebe ya da hemşireler tarafından bilgilendirilmesi daha az maliyetli ve uygun olacaktır.

Araştırmaya katılan ebeveynlerin \%57.7'si hastalık, \%38.0'i yüksek ateş durumunda rutin aşıların ertelenebileceğini ifade etmiştir. İncili'nin (2009) yaptığı bir çalışmada ise annelerin \%35'i hastalık, \%47'si yüksek ateş durumunda ertelenebileceğini belirtmiştir ${ }^{15}$. Ebeveynlerin büyük bir kısmının rutin aşıların hastalık ve yüksek ateş durumlarında ertelenebileceğini bilmeleri önemli bulunmuştur. Ancak çocukların aşılama durumlarının ertelenmesi kararını aile hekimliğinde görev alan sağlık personellerinin vermesi gerekmektedir. Ailelerin tek başına aşıların ertelenmesi kararını vermesinin kaçırılmış aşıların sayısının artmasına neden olacağı düşünülmektedir.

Aşılama, çocuklarda bağışıklamayı sağlayarak dünya çapında bulaşıcı hastalıkların mortalite ve morbidite insidansını önemli ölçüde azaltmıştır ${ }^{9}$. Uganda'da yapılan bir çalışmada annelerin \%63.9'u aşı yaptırmanın gerekli olduğunu belirtmişlerdir ${ }^{36}$. Yurt içerisinde Candan'ın (2017) yapmış olduğu çalışmada katılımcıların \%74.6'sı aşı yaptırmanın gerekli olduğunu belirtmiştir ${ }^{37}$. Bu araştırmada ebeveynlerin \%95.3'ü aşı yaptırmanın gerekli olduğunu belirtmiştir. Bu oran diğer çalışmalarla karşılaştırıldığında oldukça yüksektir. $\mathrm{Bu}$ durumda Kırıkkale ilinde aile sağlığı merkezlerinde verilen hizmetin güçlü olduğu düşünülebilir.

Anayasa Mahkemesinin aşılar hakkında 11 Kasım 2015 tarihindeki hak ihlali kararından bu yana, Türkiye'de aşılama durumu yasal olarak zorunlu değildir ${ }^{38}$. Bu araştırmadaki ebeveynlerin \%81.4'ü zorunlu aşılama programı kapsamındaki aşıların zorunlu olması gerektiğini düşünmektedir. Canbolat'ın (2018) kentsel bölgede yaptığı bir çalışmada bireylerin \%67.1'i aşıların zorunlu olması gerektiğini düşünürken, \%32.9'u zorunlu olmaması gerektiğini düşünmektedir ${ }^{39}$. Bu araştırma da diğer çalışmalarla benzerdir. Toplumun büyük bir kısmı aşılama programındaki aşıların zorunlu olması gerektiğini düşünmektedir. Ancak zorunlu olmaması gerektiğini düşünen bireylerin sayısı da az değildir. Bu da zaman içerisinde aşı reddi konusunu gündeme getirmektedir. Bir toplumda aşılara karşı reddin artması, bu durumun zaman içinde halk sağlığı sorunlarını da arttıracağını düşündürmektedir.

Ebeveynlerin sağlık okuryazarlık düzeyleri; aşılamanın öneminin kavranması, çocuk aşılama programlarına erişimin sağlanması ve aşıların tamamlanması açısından önemli görülmekle birlikte ${ }^{40}$, yapılan bazı araştırmalar sağlık okuryazarlık düzeyiyle aşılama kararları arasında herhangi bir ilişkinin olmadığını göstermiştir ${ }^{41,42}$. Bu araştırmada da ebeveynlerin sağlık okuryazarlık düzeyleri ile zorunlu aşılama programları hakkındaki düşünce arasındaki fark istatistiksel olarak anlamlı bulunmamıştır $(p=0.334)$.

\section{SONUÇ ve ÖNERILER}

Araştırmaya katılan ebeveynlerin sağlık okuryazarlık düzeyinin belirlenmesine yönelik maddelere verdiği yanıtlara göre sağlık okuryazarlığının yüksek oranda sorunlu-sınırlı düzeyde olduğu görülmüştür. Babaların annelere oranla sorunlu-sınırlı sağlık okuryazarlık düzeyinin daha yüksek olduğu tespit edilmiştir. Köy/kasabada yaşayanların yetersiz sağlık okuryazarlığı düzeyi kent merkezi ve büyükşehirde yaşayanlara oranla daha yüksek bulunmuştur. Ebeveynlerin sağlık okuryazarlık düzeyleri ile zorunlu aşılama programları hakkındaki düşünceleri arasında istatistiksel olarak anlamlı bir farklılık bulunmamıştır. Ebeveynlerin gelir ve eğitim durumları ile sağlık okuryazarlık düzeyleri arasında anlamlı bir farklılık tespit edilmemiştir. Bu sonuçlar birinci basamak sağlık hizmetlerinde çalışan hemşirelerin bireyleri değerlendirirken eğitim ve gelir durumlarından bağımsız bir şekilde sağlık okuryazarlık düzeylerini de değerlendirmesi gerektiğini düşündürmektedir. Kırıkkale'de aşı yaptırmayan ebeveynlerin olduğu mahallelerde aşı ile ilgili aile sağlığı merkezinde çalışan hemşireler tarafından gerekli bilgilendirmelerin yapılması gerektiğini düşündürmektedir. Sağlık okuryazarlık düzeyinin arttırılması ve ebeveynlerin aşılar hakkında bilgilendirilmesi amacıyla ilgili kurumların eğitim planlaması yaparak, eğitici videolar, broşürler ve afişler hazırlaması önerilir. Ayrıca bu araştırmanın ülkenin 81 ilinde yapılması ve il bazında sonuçlarıyla birlikte halk sağlığı bilgilendirme çalışmaları yapılması önerilir.

Etik Kurul Onayı: Kırıkkale Üniversitesi Girişimsel Olmayan Araştırmalar Etik Kurulu'ndan alınmıştır (Karar tarihi: 24.10.2018; Karar no: 2018.10.13).

Çıkar Çatışması: Yoktur.

Finansal Destek: Bildirilmemiştir.

Katılımcı Onamı: Ebeveynlerden bilgilendirilmiş onam alınmıştır.

Yazar Katkıları:

Araştırma dizaynı: BE, SA

Veri toplama: BE

Literatür araştırması: $\mathrm{BE}, \mathrm{SA}$

Makale yazımı: BE, SA

Teşekkür

Araştırmaya katılan tüm ebeveynlerimize teşekkür ederiz.

Ethics Committee Approval: It was taken from Kırıkkale University Non-Interventional Research Ethics Committee (Decision date: 24.10.2018; Decision no: 2018.10.13).

Conflict of Interest: None.

Funding: Not reported.

Exhibitor Consent: Informed consent was obtained from the parents.

Author contributions:

Study design: BE, SA

Data collection: $\mathrm{BE}$

Literature search: $B E, S A$

Drafting manuscript: $\mathrm{BE}, \mathrm{SA}$

Acknowledgement

Thanks to all our parents who participated in the study.

\section{KAYNAKLAR}

1. Ronson B, Rootman I. Literacy And Health Literacy: New understandings about their impact on health. Daniel Raphael (Editör). Social Determinants of 
Health: Canadian Perspectives. Toronto: Canadian Scholars' Press; 2009.

2. Australian Commission on Safety and Quality in Health Care [ACSQHC]. Health Literacy: Taking Action to Improve Safety and Quality, Avustralya [internet]. 2014 [Erişim Tarihi 31 Aralık 2018]. Erişim adresi: https://www.safetyandquality.gov.au/wpcontent/uploads/2014/08/Health-Literacy-Takingaction-to-improve-safety-and-quality.pdf

3. Nutbeam D. The evolving concept of health literacy. Soc Sci Med. 2008;67(12):2072-8.

4. Scott TL, Gazmararian JA, Williams MV, Baker DW. Health literacy and preventive health care use among medicare enrollees in a managed care organization. Med Care. 2002;40(5):395-404.

5. Görak G, Savaşer S, Yıldız S. Bulaşıcı hastalıklar hemşireliği. Ankara: Nobel Tıp Kitabevleri; 2018.

6. Australian Government: Australian Institute of Health and Welfare (AIHW). Healthy Communities: Immunisation Rates for Children in 2015-16 [Internet]. 2017 [Erişim Tarihi 12 Kasım 2018]. Erişim adresi:

https://www.myhealthycommunities.gov.au/ourreports/immunisation-rates-for-children/june-2017

7. Ekonomi Kalkınma ve İşbirliği Örgütü (Organisation for Economic Co-operation and Development [OECD]). Childhood vaccination [internet]. 2020 [Erişim Tarihi: 10 Kasım 2020] Erişim adresi: http://www.oecd.org/social/family/CO_1_4_Childh ood_vaccination.pdf

8. Maglione MA, Das L, Raaen L, Smith A, Chari R, Newberry $S$, et al. Safety of vaccines used for routine immunization of U.S. children: A systematic review. Pediatrics. 2014;134(2):325-37.

9. Frawley JE, Foley $\mathrm{H}$, Mclntyre E. The associations between medical, allied and complementary medicine practitioner visits and childhood vaccine uptake. Vaccine. 2018;36(6):866-72.

10. Dey A, Knox S, Wang $H$, Beard FH, Mclntyre PB. (2016). Summary of National Surveillance Data on Vaccine Preventable Diseases in Australia 2008-2011 [internet]. 2016 [Erişim Tarihi 25 Aralık 2018]. Erişim adresi:

http://www.health.gov.au/internet/main/publishing .nsf/Content/cda-cdi40suppl.htm

11. Sadaf A, Richards JL, Glanz J, Salmon DA, Omer SB. A systematic review of interventions for reducing parental vaccine refusal and vaccine hesitancy. Vaccine. 2013;31(40):4293-304.

12. World Health Organization. Report of the SAGE Working Group on Vaccine Hesitancy [internet]. 2014 [Erişim Tarihi: 31 Aralık 2018] Erişim adresi: https://www.who.int/immunization/sage/meetings /2014/october/1_Report_WORKING_GROUP_vaccin e_hesitancy_final.pdf

13. Wade GH. Nurses as primary advocates for immunization adherence. MCN Am J Matern Child Nurs. 2014;39(6):351-6.
14. World Health Organization (WHO). Monitoring Immunization services using the lot quality technique, Geneva: Global programme for vaccines and Immunization vaccine research and development; 1996.

15. Incili HD. Çocuk Polikliniklerimize Başvuran Çocukların Annelerinin Aşılar İle İlgili Bilgi Düzeyleri [Uzmanlık tezi]. İstanbul: T.C. Sağlık Bakanlığı Bakırköy Dr Sadi Konuk Eğitim ve Araştırma Hastanesi; 2009.

16. Abacıgil F, Harlak H, Okyay P. Avrupa Sağlık Okuryazarlığı Ölçeği Türkçe uyarlaması. Pınar Okyay, Filiz Abacıgil, (Editörler). Türkiye Sağlık Okuryazarlığı ölçekleri güvenilirlik ve geçerlilik çalışması. Ankara: Anıl Matbaa; 2016.

17. Sørensen K, Pelikan JM, Röthlin F, Ganahl K, Slonska Z, Doyle G, et al. Health literacy in Europe: Comparative results of the European health literacy survey (HLS-EU). Eur J Public Health. 2015;25(6):1053-8.

18. Tanrıöver MD, Yıldırım HH, Ready ND, Çakır B, Akalın HE. Türkiye sağlık okuryazarlığı araştırması. Ankara: Altan Özyurt Matbaacılık; 2014.

19. Çatı K, Karagöz Y, Yalman F, Öcel Y. Sağlık okuryazarlığının hasta memnuniyeti üzerine etkisi. Ekonomik ve Sosyal Araştırmalar Dergisi. 2018;14(1):67-88.

20. Öncü E, Vayısoğlu SK, Güven Y, Aktaş G, Ceyhan H, Karakuş E. Hipertansiyonu olan bireylerin kronik hastalık yönetimine ilişkin değerlendirmeleri ve sağlık okur-yazarlığı ile ilişkisi. Anatol JFM. 2018;1:312.

21. Van der Heide I, Uiters E, Sørensen K, Röthlin F, Pelikan J, Rademakers J, et al. Health literacy in Europe: The development and validation of health literacy prediction models. Eur J Public Health. 2016;26(6):906-11.

22. Deniz S, Öztaş $D$, Akbaba M. Birinci basamak sağlık hizmetlerinde çalışan sağlık personelinin sağlık okuryazarlığı düzeyi ve etkileyen faktörlerin belirlenmesi. Sakarya Tıp Dergisi. 2018;8(2):214-28.

23. HLS-EU Consortium. Comparative report of health literacy in eight EU member states. The European Health Literacy Survey HLS-EU [internet]. 2012 [Erişim Tarihi 1 Aralık 2018]. Erişim adresi: http://ec.europa.eu/eahc/documents/news/Compa rative_report_on_health_literacy_in_eight_EU_me mber_states.pdf

24. Akbolat M, Kahraman G, Erigüç G, Sağlam H. Sağlık okuryazarlığı hasta-hekim ilişkisini etkiler mi? Sakarya ilinde bir araştırma. TAF Prev Med Bull. 2016;15(4):354- 62.

25. Yamashita T, Brown JS. Does cohort matter in the association between education, health literacy and health in the USA? Health Promot Int. 2017;32(1):1624.

26. Saltık A. Anayasa Mahkemesi'nin Zorunlu Aşı Uygulamasının Yasal Düzenleme Bulunmaması Gerekçesiyle Hak İhlali Olduğuna İlişkin Bireysel 
Başvurular Üzerine Verdiği Kararların Değerlendirilmesi [Yüksek lisans tezi]. Ankara: Ankara Üniversitesi; 2018.

27. Canbolat KS. Kentsel Bölge Toplumunun Çocukluk Çağı Aşılarına Yönelik Tutumlarının Sağlık İnanç Modeline Göre Değerlendirilmesi [Yüksek lisans tezi]. Konya: Selçuk Üniversitesi; 2018.

28. Johri M, Subramanian SV, Sylvestre MP, Dudeja S, Chandra D, Koné GK, et al. Association between maternal health literacy and child vaccination in India: A cross-sectional study. J Epidemiol Community Health. 2015;69(9):849-57.

29. Pati S, Feemster KA, Mohamad Z, Fiks A, Grundmeier $R$, Cnaan A. Maternal health literacy and late Initiation of Immunizations among an Inner-city birth cohort. Matern Child Health J. 2011;15(3):386-94.

30. Duman A. Fatih ilç̧esinde Illkokul 1. Sınıf Aşılamalarında Velilerin Genel Sağlık Okuryazarlık Düzeylerini Ve Etkileyen Faktörleri Belirleme [Uzmanlık tezi]. İstanbul: İstanbul Üniversitesi; 2017.

31. Çimen Z, Temel BA. Kronik hastalığı olan yaşı bireylerde sağlık okuryazarlığı ve sağ Iık algısı ilişkisi ve sağıı okuryazarlığını etkileyen faktörlerin incelenmesi. Ege Üniversitesi Hemşirelik Fakültesi Dergisi. 2017;33(3):105-25.

32. Golboni F, Nadrian H, Najafi S, Shirzadi S, Mahmoodi $H$. Urban-rural differences in health literacy and its determinants in Iran: a community-based study. Aust J Rural Health. 2018;26(2):98-105.

33. Waters EA, Weinstein ND, Colditz GA, Emmons K. Formats for improving risk communication in medical trade off decisions. J Health Commun. 2006;11(2):167-82.

34. Galesic M, Garcia-Retamero R. Statistical numeracy for health: a cross-cultural comparison with probabilistic national samples. Arch Intern Med. 2010;170(5):462-8.

35. Amerika Birleşik Devletleri Hastalık Kontrol ve Korunma Merkezi (Centers for Disease Control and Prevention [CDC]). Immunize [internet]. 2017 [Erişim Tarihi: 24 Ocak 2019]. Erişim adresi: https://www.cdc.gov/nchs/fastats/immunize.htm

36. Avustralya Hükümeti Sağlık Departmanı [Australian Government Department of Health]. Immunisation [internet] (t.y.) [Erişim Tarihi: 23 Ocak 2019]. Erişim adresi https://beta.health.gov.au/healthtopics/immunisation/childhood-immunisationcoverage/immunisation-coverage-rates-for-allchildren

37. Taşar MA, Dallar YB. Ankara'da sosyoekonomik düzeyi düşük olan bölgede kaçırılmış aşı fırsatlarının irdelenmesi. TAF Prev Med Bull. 2015;14(4):279-83.

38. Hacettepe Üniversitesi Nüfus Etütleri Enstitüsü. 2018 Türkiye Nüfus ve Sağlık Araştırması [İnternet]. 2019 [Erişim Tarihi 7 Nisan 2020]. Erişim adresi: www.hips.hacettepe.edu.tr/tnsa2018/rapor/sonucl ar_sunum.pdf

39. Topaloğlu N, Yıldırım Ş, Tekin M, Saçar S, Peker E, Şahin EM. Üst solunum yolu enfeksiyonu geçiren çocukların ailelerinin influenza aşısı hakkındaki düşünceleri. International Journal of Clinical Research. 2013;1(1):10-13.

40. Kürtüncü $\mathrm{M}$, Alkan I, Bahadır Ö, Arslan N. Zonguldak'ın kırsal bir bölgesinde yaşayan çocukların aşılanma durumu hakkında annelerin bilgi düzeyleri. Electronic Journal of Vocational Colleges. 2017;7(1):8-17.

41. Vonasek BJ, Bajunirwe $F$, Jacobson LE, Twesigye L, Dahm J, Grant MJ, et al. Do maternal knowledge and attitudes towards childhood immunizations in rural uganda correlate with complete childhood vaccination? PLOS ONE. 2016;11(2): e0150131.

42. Candan H. Bir Üniversite Hastanesi Aile Hekimliği Polikliniği'ne Başvuran Hastaların Erişkin Aşıları Hakkındaki Farkındalıklarının ve Mevcut Erişkin Aşılanma Durumlarının Tespiti ve Değerlendirilmesi [Tıpta uzmanlık tezi]. Ankara: Ankara Üniversitesi; 2017 